\title{
28
}

\section{Multiparty cabinet and power-sharing: lessons from elsewhere ${ }^{1}$}

\section{Jon Fraenkel}

The ultimate outcome of Fiji's 2006 election was paradoxical. In some respects, it was the most polarized election in Fiji's history. ${ }^{2}$ The two major parties, each with unanimous support from their respective ethnic communities, were able to divide up all the Fijian and Indian communal seats, as well as all the open seats. ${ }^{3}$ Yet, in the aftermath of the election, the formation of a multiparty cabinet represented a historically unprecedented effort at power-sharing between the leaders of Fiji's two major communities.

The idea that some kind of coming-together in cabinet of leaders representing Fijis different ethnic communities might provide some means of getting beyond Fiji's communalist impasse was not new. It had been raised during Ratu Sir Kamisese Mara's period as prime minister in the late 1970s, but never got off the ground. It was entrenched in the 1997 constitution by the then prime minister, Sitiveni Rabuka, and by then opposition leader Jai Ram Reddy, but they lost the 1999 election. ${ }^{4}$ A multiparty cabinet was formed after the 1999 election, but it did not include the party with the largest share of the indigenous vote (Rabuka's Soqosoqo ni Vakavulewa ni Taukei (SVT), which won 38 per cent of the Fijian vote in 1999). Instead, the Fiji Labour Party (FLP) obtained an absolute majority (with 37 of the 71 seats) and, although it formed a coalition with several smaller Fijian parties, the emergence of splits within these Fijian allied parties generated difficulties for the multiparty cabinet even before the coup of 19 May 2000. 
Such splitting is always a difficulty with multiparty cabinets; the minority party or parties run the risk of being seen as powerless within cabinet and lose popular support. None of the indigenous Fijian politicians who participated in the 1999 cabinet proved able to secure re-election in majority Fijian electorates in either 2001 or 2006 . The key challenge for the post-2006 election multiparty cabinet was to achieve real influence for the minority party, and enable its leaders to sustain popular Fiji Indian backing for their participation in cabinet.

Fiji is not alone in looking to power-sharing as the answer to long-standing political polarization, but the country does have some uniquely favourable circumstances that might make it possible to avoid the type of difficulties experienced elsewhere.

Many of the world's experiments in power-sharing - for example, those in Africa - have occurred in post-civil war circumstances. The protagonists have armies stationed in different parts of the country, and the power-sharing arrangements often attempt to bring these together. So great is the bitterness between former combatants that these arrangements are often used to gain strategic advantage - and regularly fall apart. ${ }^{5}$ Fiji is fortunate not to have this experience of civil warfare and violence; polarization has been largely political, while relationships at the grass roots level have remained reasonably amicable. As incoming FLP cabinet minister Krishna Datt put it shortly after the 2006 poll, political leaders have at times behaved like burlesque American wrestlers feigning fights with each other, instead of seeking cooperative ways to manage the affairs of state. ${ }^{6}$

The best-known modern power-sharing experiment was that adopted as part of the South African 1994 constitution by Nelson Mandela and F.W. de Klerk, and this influenced the design of Fiji's own institutions. The ability of those leaders to transcend ethnic politics, and establish for that country a more accommodative style of politics made a decisive difference, not just for that country, but more broadly for the southern part of Africa. ${ }^{7}$ Yet, in other respects, South Africa is a poor model for Fiji. There, arrangements were inevitably temporary, and were aimed at reassuring the white minority during the transition away from apartheid. F.W. de Klerk's National Party pulled out of the cabinet in 1996, and, in the same year, a new permanent constitution abandoned the multiparty cabinet provisions. Power-sharing, of a sort, 
continued, but it was no longer mandatory. Fiji's situation is very different; here, the two populations are much closer in size than those of Africans and whites in South Africa and, owing to this, the multiparty cabinet provisions are potentially longer-term, rather than temporary, arrangements.

Northern Ireland has also pursued an experiment in power-sharing, as part of the 1998 Anglo-Irish Good Friday Agreement, but ongoing tensions between Loyalists and Republicans have delayed the implementation of the powersharing rules. There, it is pressure from the British and Irish governments that has provided the critical encouragement to power-sharing, whereas in Fiji the incentives are largely domestic. In many ways, this is a great, and insufficiently recognized, advantage: for Fiji, the desire to make these arrangements work is not driven primarily by overseas links (important though those may be in the future if managed sensitively). Rather, Fiji's more astute politicians have recognized the advantages that can potentially be secured by having a government that rules by consensus and draws on the reservoirs of talent in both communities.

Neighbouring New Caledonia also has a multiparty cabinet experiment, although one that has not received the international attention it deserves. Back in the mid-1980s, that territory was close to a civil war between mainly Kanak-backed, pro-independence groups and the mainly settler-backed government. The 1988 Matignon Accord provided an initial agreement centred on devolution of powers to the three provinces (something, incidentally, never tried in Fiji for various reasons). A decade later, the 1998 Noumea Accord provided for a power-sharing territorial executive, coupled with steady transfer of powers from Paris to Noumea. The result has been a transformation of the New Caledonian political scene, with Kanak leaders participating in cabinet and a reconfiguration of political alliances on both sides. ${ }^{8}$

There are many other international experiences with power-sharing; some more successful, others less successful. Switzerland, for example, has nearly a century of experience with a Federal Council, which brings together representatives of the German-, French- and Italian-speaking minorities. Several of the other continental European states - including Austria and Belgium - also have experience with power-sharing institutions. There are also some notorious failures - Cyprus in the 1960s or Lebanon in the 1970s, for example. In the Lebanese case, external factors played an important role in the breakdown of 
the post-war national pact, even if the inflexibility of domestic arrangements - and in particular the 6:5 ratio of parliamentarians in favour of Christians over Muslims - also generated difficulties. Nevertheless, when former adversaries finally sought to end the civil war that had so ravaged the country from the mid-1970s to the 1990s, they almost inevitably reverted to a new powersharing agreement (the 1989 Ta' if Accord), although one that entailed a shift to parity between Christian and Muslim MPs, a stronger role for the Muslim prime minister and a less powerful role for the Maronite Christian president. Similarly, in Bosnia and Iraq, the settlement of severe conflict critically depends on some commitment to the sharing of power in cabinet.

Surveying the global power-sharing experience suggests that, while the provisions adopted in different parts of the world differ markedly, there are some important common features that help to explain the success or failure of accords. What lessons can be learned from the international experience?

\section{An effective voice for minority representatives}

Power-sharing cabinets need to provide an effective voice for those politicians representing the minority community (or smaller party or parties). There is always a danger that the majority community's leaders will view the multiparty cabinet as a vehicle for rubber-stamping their own program, and deny minority leaders an effective voice, so that the latter come to be seen as unrepresentative 'Uncle Tom'-type figures. This is sometimes dealt with by having a minority veto, although such provisions run the risk of generating gridlock and immobilism. Effective multiparty cabinets enable parties to bring their own policies and perspectives into cabinet, and to establish some kind of balance between different interests through negotiation. In New Caledonia, this has also been much debated, with discussion centring on the meaning of the Noumea Accord's provisions for 'collegiality' in cabinet. The success or failure of Fiji's 2006 experiment will depend on the minority party being able to demonstrate greater influence in determining policy than was the case for the smaller parties in the 1999-2000 cabinet.

Multiparty cabinets, where both parties have strong support from the peoples they represent, have the advantage over multi-ethnic cabinets in that they bring a more genuinely representative mix into cabinet. Under Ratu Mara's Alliance 
Party governments in the 1970 s and 1980s, there were repeated efforts to create multi-ethnic governments, but these never received majority support from the Indian community. Those who crossed over to join Ratu Mara's cabinets tended, as a result, to lose their seats at the following election, or to be seen as unrepresentative leaders. Muslim cabinet minister Ahmed Ali, for example, was the Indian member for the Lau constituency, where the electorate was overwhelmingly Fijian. He once described trying to forge links with the Indian community as being like trying to build a house by putting the roof on first. ${ }^{9}$ Where, instead, the undisputed leaders of the Indian community join the cabinet there is the potential for a more genuine type of accommodation.

\section{The need for real accomplishments}

Power-sharing governments need to show genuine accomplishments. One of the weaknesses of the Rabuka-Reddy Accord back in 1996 was that the two subsequent years did little to demonstrate to the electorate the advantages of the new cooperative arrangements. Inertia set in. 1997, for example, was also the year when thousands of Agricultural Landlord and Tenant Act (ALTA) leases began expiring, resulting in severe hardship for the Fiji Indian rural communities. Almost ten years later, in 2006, the ALTA expiry issue remains unresolved. Partly as a result of this failure to deliver concrete achievements connected with sharing power, both Rabuka's SVT and Reddy's National Federation Party proved unable to hold the support of their respective communities at the 1999 poll, and the consequence was a rocky ride for the new constitution.

In the wake of the formation of the 2006 power-sharing executive, some suggested that potentially controversial legislation should be shelved or abandoned, and that discussion of some of the thorny issues should be deferred. Such delay would have the potential to quickly exhaust the new power-sharing government's post-election honeymoon. Without real accomplishments on ethnically sensitive issues, two or three years down the line, criticism of ministers enjoying perks and Pajeros would inevitably feature in the media reports, and/ or government backbenchers would become more restive. Ethnic out-bidders would find themselves getting a wider hearing, putting pressure on their more moderate colleagues in cabinet. 
Timing is also important for other reasons. Power-sharing arrangements, like coalition governments more generally, frequently break down beyond the middle of a parliamentary term, ahead of impending general elections, as political parties seek to re-galvanize support among core electorates. At that stage, minority parties in cabinet often look for potent issues around which to make a break from cabinet, hoping that electorates will punish the governing party for any breakdown in coalition arrangements.

An approach more likely to cement power-sharing arrangements is to demonstrate to the public real gains to people's living standards, that arise out of the new cooperation in cabinet. Fiji's economic growth and investment levels have been seriously diminished by political instability and civil strife. As a result, there exists scope for substantial gains should that epoch in Fiji's history now be closed. Even prior to the 2006 election, some politicians were collaborating together in the government select committees on land and sugar issues, and aiming to arrive at real solutions to these pressing questions. The land-leasing question, in particular, is an issue that is susceptible to some accommodative resolution (although not, as some propose, by creating an additional tier of state bureaucracy to deal with leasing).

The Promotion of Reconciliation, Tolerance and Unity (RTU) Bill is another issue that could either break up the multiparty cabinet or, if handled sensibly and sensitively, show real gains for cooperation in cabinet. The government's desire to draw a line under the experience of the 2000 coup, and to open a new chapter in Fiji's history was understandable. It has been the amnesty provisions of the RTU Bill that generated the most concern, on the grounds that they might facilitate the release of those convicted for involvement in the 19 May 2000 coup or the 2 November 2000 mutiny at the army's Queen Elizabeth Barracks. There is a possibility for compromise here too; a thoughtful amendment to the Bill could address the concerns of the minority community that the arrests and convictions after 2000 should stand out as an emphatic warning against any return to Fiji's cycle of coups, but still put in place machinery that assists the country in shifting beyond the fraught experience of the 2000 coup. 


\section{Visionary leaders and change in political parties}

Power-sharing arrangements need the engagement of visionary leaders, and political parties often need to change substantially to make these work effectively. Power-sharing arrangements depend on the ability of political leaders to transform the parties they represent. Mandela's role in changing the African National Congress away from the politics of confrontation, and de Klerk's similar role in relation to the National Party were crucial in ensuring the success of the transition in South Africa. Conversely, Ian Paisley and other Loyalist leaders' resistance to the implementation of the 1998 Anglo-Irish Good Friday Agreement have proved an obstacle to the constructive continuation of the peace process in Northern Ireland. The sudden death of political leaders who provide the critical inspiration behind power-sharing accords (as in New Caledonia or Sudan ${ }^{10}$ ), inevitably entails a bumpy ride for the new arrangements. If the leader of one of the cooperating parties stands outside the multiparty cabinet, its chances of success are, inevitably, slim. The post-2006 election power struggle in the FLP was an almost inevitable result of party leader Mahendra Chaudhry's decision to remain outside the cabinet. In South Africa or Northern Ireland, the FLP leader would have been entitled to a vice presidency or deputy chief minister position, an arrangement that is probably the logical counterpart of effective power-sharing arrangements where these involve two large communities.

As they adjust to sharing power after a period of bitter antagonism, both majority and minority party leaders inevitably face difficulties in managing internal party affairs. The majority party leader is potentially threatened by government backbenchers eager for portfolios should power-sharing arrangements fall apart. The minority party leader may face charges of 'selling out' his or her community. In Fiji's post-2006 case, the FLP leader stayed outside the cabinet and FLP ministers were subjected to disciplinary charges for breaching party policy. The alternative of a breakaway faction separating from the FLP was, perhaps fortunately in this context, legally discounted by constitutional provisions against party-hopping. ${ }^{11}$ FLP ministers seeking to align themselves outside the party would have to face by-elections in their constituencies; this would potentially require them to cross the difficult hurdle of over-turning the strong support for the FLP shown at the 2006 polls in 
Indian electorates. Differences are inevitable under Fiji's multiparty cabinet arrangements, and are best dealt with by thoughtful and flexible negotiation within political parties as much as within cabinet.

\section{Government and opposition}

Power-sharing arrangements entail a reconfiguration of the 'opposition' and other constitutional arrangements. Internationally, power-sharing arrangements are normally associated with a shift away from the Westminster-style government opposition model. Normally, there is no leader of the opposition. Instead, backbenchers - whichever political party they are associated with - serve as the check on government policy, as with the Bereichsopposition during the time of the Austrian grand coalition. ${ }^{12}$ Fiji's constitution remains ambiguous in this respect because the multiparty cabinet provisions were added later, superimposed after the assembly of a Westminster-based framework. This has resulted in all sorts of anomalies. For example, the constitution provides for a proportional distribution of the senate nominees from the leader of the opposition, but not those from the prime minister. The precise interpretation of the cabinet proportionality provisions in section 99 (5) of the constitution was an issue of continual litigation in the Court of Appeal and Supreme Court after the 2001 poll, with the decision of September 2004 placing judges in the position of being effectively law-makers rather than interpreters of the law. ${ }^{13}$ Not having a limit on cabinet size was also unfortunate, because the requirement to retain dual majorities inevitably imparts an inflationary impetus to cabinet formation (New Caledonia, it should be noted, does have an 11 -member limit on cabinet size). ${ }^{14}$ Rules about 'cabinet confidentiality' and 'collective responsibility' also reflect the Westminster tradition, rather than the more flexible type of arrangements normally found in power-sharing executives.

\section{Affirmative action programs}

Affirmative action programs often accompany power-sharing provisions, but these work best if they relate to distribution of gains arising from a higher rate of economic growth, and if they are oriented towards all disadvantaged groups rather than one or the other ethnic group. In many countries that have looked to power-sharing rules to find a route away from political polarization, 
improving the position of disadvantaged communities has been important. Even where the differences are small, as between the Catholics and Protestants in Northern Ireland, improvements in living standards for the more disadvantaged community can make a big difference (improving prosperity in largely Catholic Southern Ireland had significant knock-on effects for Northern Ireland's Catholics). In New Caledonia, the Matignon and Noumea Accords have been accompanied by heavy French expenditures aimed at rééquilibrage ('rebalancing') to improve the position of the Kanaks. As in Fiji, those provisions often stimulate criticism that more is being done to foster the emergence of an indigenous élite than to improve general living standards. Nevertheless, those affirmative action policies have proved important in changing the orientation of the political leadership on both sides in New Caledonia, and are intimately connected with the success of the power-sharing accords.

In Fiji, discussions of relative indigenous disadvantage often occur in a time warp. It is as if nothing has changed since the time of the Spate (1959) and Burns (1960) reports, when around 90 per cent of indigenous Fijians still lived in rural villages, when there were few Fijian professionals, and when Fijians scarcely participated in the formal sectors of the economy (other than in the civil service, on the docks and in the gold mines). ${ }^{15}$ Yet, this position has changed vastly, and not primarily due to affirmative action programs. Even before the unravelling of the Fijian Regulations in the mid-1960s, many ethnic Fijians had moved towards the towns. In the 1970s and 1980s, Fijian participation in formal sector employment grew strongly. Nevertheless, household income and expenditure surveys in 1977 and the early 1990s showed Fijians, on average, to be worse off than Fiji Indians. ${ }^{16} \mathrm{~A}$ big part of the reason had to do with poverty in Fijian rural villages, although there was also evidence of urban poverty. Those studies found that, although Fijians were on average worse off than Fiji Indians, income inequality was more severe amongst Fiji Indians. So the lowest 20 per cent of Indian income-earners were somewhat worse off than their Fijian counterparts.

Fears are often expressed that affirmative action programs, particularly those aimed at encouraging indigenous businesses, are disproportionately aimed at élites. But there are alternative ways of handling such policies that earn greater legitimacy. Notably, the once heavily criticised Malaysian model of affirmative 
action is now much more internationally favoured, to a large degree because it became increasingly growth-oriented - rather than simply aimed at dividing up a diminishing or stagnant pie - and because it became aimed at all disadvantaged groups rather than favouring only one of the country's ethnic groups. Politicians in Fiji tend to feign a division on principle in relation to affirmative action; the Labour Party, when in power, accepted the need for programs that were aimed at tackling indigenous disadvantage. So, the issue is how to establish some degree of consensus around policies that have the effect of improving the situation of Fijians without being viewed as excessively ethnically slanted.

This list of important lessons from the international experience is not exhaustive; there are many others that merit consideration. But the list highlights some of the core issues that will need to be addressed, preferably through negotiation and compromise rather than through excessive resort to the law courts. If this is accomplished, ten years down the road, it might be Fiji that becomes the model to which other countries look, rather than Fiji looking to other countries to find examples of how to make power-sharing work effectively.

\section{Notes}

1 This chapter provides a modified and extended version of a keynote address to the Ministry of Multi-Ethnic Affairs, National Reconciliation \& Unity Seminar on 'National Identity and Multi-Culturalism', Holiday Inn, 19 July 2006. It is included as a time-specific chapter, addressing the issues of the day, and steers clear of avoiding any prediction as regards the likely survival or failure of the post-2006 multiparty cabinet arrangements.

2 Meaning by this not that the conduct of the election was any more venomous than previously, but rather that there were fewer splinter parties representing each group. In all other postindependence elections, minority parties were able to get a seat or two, either in Fijian or 'national' (1972-87) or 'open' (1999-2006) constituencies.

3 The only space for other parties or independents was in the General or Rotuman constituencies.

4 'In establishing the cabinet, the prime minister must invite all parties whose membership in the House of Representatives comprises at least 10 per cent of the total membership of the House to be represented in proportion to their numbers in the House' [Fiji Government, 1997 Constitution, S.99(5)].

5 Spears, I.S. 2002. 'Africa: The Limits of Power-Sharing', Journal of Democracy, 13(3).

6 Parliament of Fiji, Parliamentary Debates, Daily Hansard, 8 June 2006; http://www. parliament.gov.fj/hansard

7 Koelble, T. \& Reynolds, A. 1996. 'Power-sharing democracy in the new South Africa', Politics and Society, 24(3):221-36. 
8 Maclellan, N. 2005. 'From Eloi to Europe: interactions with the ballot box in New Caledonia', Commonwealth \& Comparative Politics, 43(3):394-417.

9 Ali, A. 1997. 'The Fiji general election of 1977', Journal of Pacific History, 12(4):195.

10 FLNKS leader Jean-Marie Tjibaou was assassinated on 4 May 1989, shortly after the Matignon Accord had been signed. Sudan Peoples' Liberation Movement leader John Garang died in a helicopter crash in July 2005, only months after becoming vice president in a power-sharing deal ('The death of John Garang', Economist, 4 August 2005).

11 'The place of a member of the House of Representatives becomes vacant if the member... (g) resigns from the political party for which he or she was a candidate at the time he or she was elected to the House of Representatives;

(h) is expelled from the political party for which he or she was a candidate at the time he or she was last elected to the House of Representatives and:

(i) the political party is registered

(ii) the expulsion was in accordance with the rules of the party relating to party discipline; and

(iii) the expulsion did not relate to action taken by the member in his or her capacity as a member of a parliamentary committee' [Constitution of the Republic of the Fiji Islands, 1997, S 71. (1)].

12 Personal communication, Arend Lijphart, 1 June 2006; Lijphart, A. 1977. Democracy in Plural Societies: A Comparative Exploration, Yale University Press, p.48.

13 On the history of these decisions, see the multiparty cabinet time-line produced as an appendix to this volume.

14 By requirement to maintain dual majorities, I mean that Fiji governments have, potentially, to be formed twice. Initially, the onus is on a potential prime minister to persuade the president that he or she can command the support of a majority in the House. The president offers the premiership to the 'member of the House of Representatives who, in the President's opinion, can form a government that has the confidence of the house' (1997 constitution S. 98). Where a coalition is required, this is likely to be accompanied by inter-party agreements about the distribution of ministerial portfolios. Once appointed, the prime minister must reform his or her government in accordance with the 10 per cent entitlement provision, often incorporating parties from the opposite end of the political spectrum.

15 Only 11 per cent of Fijians were recorded as resident in the urban areas at the 1956 census (Colony of Fiji, Report on the Census of Population, 1956, Legislative Council of Fiji, Council Paper No 1 of 1958, Government Press, Suva, 1958).

16 See Stavenuiter, S. 1983. Income Distribution in Fiji, ILO, Suva; UNDP Fiji Poverty Report, 1996; Ahlburg, D.A. 1996. 'Income Distribution and Poverty in Fiji', UNDP, Suva. 